\title{
IDENTIFIKASI DAN ANALISIS RISIKO PROYEK PADA MASA KONSTRUKSI BANGUNAN BERTINGKAT 4-40 LANTAI DI JABOTABEK TERHADAP RUANG LINGKUP, JADWAL, DAN SUMBRER DAYA PROYEK
}

\author{
Luther Gustavo Liwoso'), Setiono'), Sugiyarto ${ }^{3)}$ \\ 1) Mahasiswa Jurusan Teknik Sipil, Fakultas Teknik, Universitas Sebelas Maret, Jl. Ir. Sutami 36 A Surakarta \\ 2) Pengajar Jurusan Teknik Sipil, Fakultas Teknik, Universitas Sebelas Maret, Jl. Ir. Sutami 36 A Surakarta \\ 3) Pengajar Jurusan Teknik Sipil, Fakultas Teknik, Universitas Sebelas Maret, Jl. Ir. Sutami 36 A Surakarta \\ Email: luthergustavoliwoso@gmail.com
}

\begin{abstract}
Project constructions always related with risks or hitchs during the construction phase. These risks are dynamic and can change so that risk variables are difficult to predict. Therefore, the risk management planning is needed in order to achieve project goals which include project scope, schedule and resources. This research was conducted with the aim of (1) Knowing the risk variables that have a negative impact and affect the project objectives, (2) Knowing the results of the analysis of the risk variables that have been identified, and (3) Knowing how the handling is carried out by the contractor in overcoming the risk variables variables that bave been analyzed. The research strategy was carried out by means of a survey which uses instruments form like questionnaires and interviews with 38 respondents. The analysis method used in this research is descriptive statistical analysis, frequency analysis, ranking analysis, and level analysis. The results showed that (1) Obtained 50 types of risk variables that have negative impact which is divided into 20 types of risk variables that have an effect on the project schedule, 14 types of risk variables that bave an effect on project resources, and 16 types of risk variables that have an effect on project scope, (2) Obtained 6 main project risks, namely X31 Disease Fever During Project Implementation Affects Most of the Workforce, X43 Complex Structure Is Designed Separately (Precast) but the Integration Process Fails to Implement, X42 Structure Collapse in the Middle of Construction, X46 Work and Retesting is Needed to Repair Incorrect Work Results, X20 Laborers Strike Work, and X21 Delayed Projects Make the Budget Increase, also (3) Obtained the risk management handlings that can be carried out by the contractor on the risk variables that have been analyzed which divided into 7 handling of risks in the project scope, 4 handling of risks in the project schedule, and 4 handling of risks in the project resource.
\end{abstract}

Keywords: Risk, Scope, Schedule, Resources.

\begin{abstract}
ABSTRAK
Proyek konstruksi selalu memiliki hubungan dengan risiko atau hambatan pada masa konstruksi. Risiko-risiko tersebut bersifat dinamis dan dapat berubah sehingga variabel risiko sulit untuk diprediksi. Oleh karena itu, perencanaan manajemen risiko dibutuhkan guna mencapai sasaran proyek yang meliputi ruang lingkup, jadwal, dan sumber daya proyek. Penelitian ini dilakukan dengan tujuan untuk (1) Mengetahui variabelvariabel risiko yang berdampak negatif dan berpengaruh terhadap sasaran proyek, (2) Mengetahui hasil analisis variabel-variabel risiko yang telah diidentifikasi, serta (3) Mengetahui bagaimana penanganan yang dilakukan oleh kontraktor dalam mengatasi variabel-variabel risiko yang telah dianalisis. Strategi penelitian dilakukan dengan cara survey dimana instrumen yang digunakan adalah kuisioner dan wawancara terhadap 38 orang responden. Metode analisis yang digunakan adalah analisis statistik deskriptif, analisis frekuensi, analisis ranking, dan analisis level. Hasil penelitian menunjukkan bahwa (1) Diperoleh 50 jenis variabel risiko yang memberikan dampak negatif dimana 20 jenis variabel risiko berpengaruh terhadap jadwal proyek, 14 jenis variabel risiko berpengaruh terhadap sumber daya proyek, dan 16 jenis variabel risiko berpengaruh terhadap ruang lingkup proyek, (2) Diperoleh 6 risiko utama proyek, yaitu X31 Demam Penyakit Selama Pelaksanaan Proyek Menimpa Sebagian Besar Tenaga Kerja, X43 Struktur Kompleks Didisain Terpisah (Precast) namun Proses Integrasi Gagal untuk Diterapkan, X42 Robohnya Struktur di Tengah Pelaksanaan Konstruksi, X46 Dibutuhkan Pekerjaan dan Penguijan Ulang untuk Memperbaiki Hasil Pekerjaan yang Salah, X20 Buruh Melakukan Mogok Bekerja, dan X21 Proyek yang Terlambat Membuat Budget Bertambah, serta (3) Diperoleh penanganan risiko yang dapat dilakukan kontraktor terhadap variabel-variabel risiko yang telah dianalisis dimana 7 penanganan terhadap risiko ruang lingkup proyek, 4 penanganan terhadap risiko jadwal proyek, dan 4 penanganan terhadap risiko sumber daya proyek.
\end{abstract}

Kata Kunci: Risiko, Ruang Lingkup, Jadwal, Sumber Daya. 


\section{PENDAHULUAN}

Besarnya laju pertumbuhan dan jumlah penduduk di JABOTABEK perlu diimbangi peningkatan sarana dan prasarana dalam menunjang berbagai kebutuhan yang diperlukan, hal ini menjadi salah satu hal yang paling diminati bagi para pengusaha dalam melakukan investasi terutama di bidang konstruksi pembangunan. Proses pembangunan yang terjadi tidak lepas dari adanya hambatan atau kendala-kendala yang dapat berdampak secara langsung maupun tidak langsung dalam keberjalanan suatu proyek konstruksi. Kendala-kendala yang terjadi pada umumnya merupakan permasalahan yang sering terjadi dalam dunia konstruksi seperti permodalan, penngelolaan, pemasaran, ataupun sistim manajemen.

Tiga faktor penentu yang dapat menjadi tolak ukur suatu sistim manajemen dapat dikatakan baik adalah ruang lingkup, jadwal, dan sumber daya proyek. Tiga hal tersebut juga menjadi indikator utama keberhasilan suatu proyek konstruksi, oleh sebab itu perlu dikaji sistim pengelolaannya. Diharapkan, dengan adanya sistim manajemen risiko mengenai sasaran proyek tersebut dapat mengatasi bahkan menghindari terjadinya kesalahan kerja sehingga tidak mengganggu jadwal dan anggaran yang telah direncanakan.

\section{METODE PENELITIAN}

\section{Instrumen Penelitian}

Pada penelitian ini, variabel risiko proyek yang digunakan sebagai bahan pengujian adalah variabel-variabel risiko yang terjadi pada masa konstruksi dan berdampak negatif terhadap ruang lingkup, jadwal, dan sumber daya proyek. Strategi penelitian dilakukan dengan cara survey dimana untuk mengatasi karakteristik survey yang tidak memiliki kendali terhadap peristiwa yang akan diteliti, maka digunakan instrumen penelitian berupa kuisioner dan wawancara.

\section{Variabel Penelitian}

Variabel-variabel risiko yang digunakan dalam penelitian ini diperoleh dari hasil pembacaan studi literatur dan wawancara terhadap 38 orang responden yang merupakan para pekerja, staff, dan manager kontraktorkontraktor yang bergerak di bidang pembangunan gedung bertingkat tinggi di JABOTABEK.

\section{Pengumpulan Data}

Pada tahap pengumpulan data dalam penelitian ini, diperoleh variabel-variabel risiko proyek pada masa konstruksi bangunan bertingkat 4-40 di JABOTABEK terhadap ruang lingkup, jadwal, dan sumber daya proyek serta rekapitulasi jawaban responden terhadap masing-masing variabel risiko yang diberikan dalam skala $1-5$.

\section{Pengujian Data}

Sebelum digunakan untuk proses analisis data, jawaban responden mengenai variabel-variabel risiko yang diberikan perlu diuji terlebih dahulu sehingga data yang didapat valid dan reliabel untuk digunakan. Pengujian yang dilakukan adalah uji validitas dan uji reliabilitas data.

\section{Pengolahan Data}

Pengolahan data dilakukan untuk mencari Nilai Level Indeks Risiko (I). Adapun tahapan pengolahan data yang dilakukan sebagai berikut:

1. Menentukan nilai yang diberikan untuk Frekuensi Risiko (F).

2. Menentukan nilai yang diberikan untuk Pengaruh Risiko $(G)$.

3. Menentukan nilai Indeks Risiko $(\mathrm{H})$ dengan mengalikan nilai Frekuensi Risiko dengan nilai Pengaruh Risiko (F $x \mathrm{G})$.

4. Menentukan nilai minimum, maksimum, rentangan, dan batas level.

5. Mendefinisikan harga dari skala 1-5.

6. Menentukan nilai Level Indeks Risiko (I). 


\section{Validasi Data}

Proses validasi dilakukan Bersama dengan para pakar yang mengerti mengenai variabel-variabel risiko pada proyek pembangunan gedung bertingkat tinggi di JABOTABEK guna menarik kesimpulan yang berupa penanganan risiko sesuai dengan sasaran proyek.

\section{HASIL DAN PEMBAHASAN}

\section{Identifikasi Risiko}

Identifikasi risiko dilakukan untuk menentukan variabel-variabel risiko yang relevan untuk digunakan sebagai data penelitian. Adapun identifikasi yang didapat sesuai dengan sasaran proyek yang meliputi ruang lingkup, jadwal, dan sumber daya proyek. Variabel-variabel hasil identifikasi dapat dilihat pada tabel 1-3.

Tabel 1 Variabel Risiko Ruang Lingkup Proyek

\begin{tabular}{|c|l|}
\hline No & \multicolumn{1}{|c|}{ Variabel Risiko } \\
\hline 1 & Disain ulang sistem struktur terlambat dimasukkan ke dalam pengelolaan proyek \\
\hline 2 & Perubahan kebijakan perusahaan menambah pekerjaan yang tidak direncanakan \\
\hline 3 & Pekerjaan telah diselesaikan oleh kontraktor tetapi tidak sesuai dengan harapan (scope) \\
\hline 4 & Hasil pekerjaan (deliverable) gagal pada pengujian akhir \\
\hline 5 & Disain proyek tidak bersifat konstruktif \\
\hline 6 & Ddisain ulang pekerjaan yang dibutuhkan terlambat sehingga menyebabkan kesalahan kerja \\
\hline 7 & Kesalahan dalam penentuan peralatan konstruksi \\
\hline 8 & Robohnya struktur di tengah pelaksanaan konstruksi \\
\hline 9 & Struktur kompleks didisain terpisah (precast) namun proses integrasi gagal untuk diterapkan \\
\hline 10 & Teknologi baru yang direncanakan tidak sesuai harapan \\
\hline 11 & Tidak adanya manajemen perubahan saaat proyek berlangsung \\
\hline 12 & Dibutuhkan pekerjaan dan pengujian ulang untuk memperbaiki hasil pekerjaan yang salah \\
\hline 13 & Hasil pekerjaan (deliverable) dari subkontraktor tidak berkualitas \\
\hline 14 & Izin yang diperlukan proyek tidak disetujui \\
\hline 15 & Hasil pekerjaan (deliverable) proyek merugikan pihak lain atau masyarakat setempat \\
\hline 16 & Terjadi kecelakaan pekerjaan yang merugikan dan menimpa masyarakat \\
\hline
\end{tabular}

Tabel 2 Variabel Risiko Jadwal Proyek

\begin{tabular}{|c|l|}
\hline No & \multicolumn{1}{|c|}{ Variabel Risiko } \\
\hline 1 & $\begin{array}{l}\text { Masing-masing stake holder menyetujui metode pelaksanaan proyek, tetapi pada } \\
\text { pelaksanaannya pertentangan muncul sehingga proyek mengalami keterlambatan }\end{array}$ \\
\hline 2 & $\begin{array}{l}\text { Akses kepada pimpinan manajemen proyek dibatasi sehingga keputusan dan eskalasi } \\
\text { menjadi terlambat }\end{array}$ \\
\hline 3 & Sistem pengujian lelang di sebarkan oleh beberapa proyek sehingga antrian bertambah \\
\hline 4 & $\begin{array}{l}\text { Tidak terjadi koordinasi antarstaff saat pekerjaan proyek berlangsung menyebabkan } \\
\text { terjadinya kesalahan dan keterlambatan kerja }\end{array}$ \\
\hline 5 & $\begin{array}{l}\text { Terlalu optimis pada tanggal penyelesaian pekerjaan berdampak terhadap deadline yang tidak } \\
\text { tercapai }\end{array}$ \\
\hline 6 & $\begin{array}{l}\text { Teknologi baru yang direncanakan untuk digunakan ke dalam proyek tidak tersedia pada } \\
\text { waktunya }\end{array}$ \\
\hline
\end{tabular}


Tabel 2 Variabel Risiko Jadwal Proyek (Lanjutan)

\begin{tabular}{|c|l|}
\hline No & \multicolumn{1}{|c|}{ Variabel Risiko } \\
\hline 7 & $\begin{array}{l}\text { Spesifikasi kelayakan alat yang digunakan dalam pekerjaan sudah tua dan tidak semua } \\
\text { pekerja menguasai alat tersebut, serta tidak ada dokumentasi proses penggunaan alat }\end{array}$ \\
\hline 8 & Sistem untuk menyetujui permintaan gagal sehingga pemesanan material terlambat \\
\hline 9 & $\begin{array}{l}\text { Penerapan sistem baru pada konstruksi yang digunakan salah sehingga menyebabkan } \\
\text { keterlambatan }\end{array}$ \\
\hline 10 & $\begin{array}{l}\text { Sistem yang dibutuhkan untuk pengaturan jadwal rencana kerja (scheduled) tidak sesuai } \\
\text { rencana }\end{array}$ \\
\hline 11 & Produktivitas tenaga kerja tidak sesuai yang direncanakan \\
\hline 12 & $\begin{array}{l}\text { Perkembangan jadwal rencana kerja (scheduled) terjadi secara bersamaan di berbagai } \\
\text { pekerjaan sehingga terjadi salah koordinasi }\end{array}$ \\
\hline 13 & $\begin{array}{l}\text { Keterampilan yang dimiliki staff baru tidak sesuai yang diharapkan sehingga dibutuhkan } \\
\text { pelatihan terlebih dahulu }\end{array}$ \\
\hline 14 & Pencapaian lokasi proyek yang sulit membuat para pekerja datang terlambat \\
\hline 15 & Terjadi kecelakaan tenaga kerja \\
\hline 16 & Demam penyakit selama pelaksanaan proyek menimpa sebagian besar tenaga kerja \\
\hline 17 & $\begin{array}{l}\text { Perubahan definisi scope terlambat yang berakibat tidak tercapainya scope proyek yang } \\
\text { baru }\end{array}$ \\
\hline 18 & $\begin{array}{l}\text { Prioritas proyek tidak jelas dimana pekerjaan yang kurang penting diselesaikan lebih dahulu } \\
\text { dibandingkan dengan pekerjaan yang seharusnya lebih dibutuhkan }\end{array}$ \\
\hline 19 & $\begin{array}{l}\text { Informasi sistem baru menyebabkan terjadinya penambahan pekerjaan di luar scope proyek } \\
\text { yang telah direncanakan }\end{array}$ \\
\hline 20 & Terjadi kecelakaan tenaga kerja \\
\hline
\end{tabular}

Tabel 3 Variabel Risiko Sumber Daya Proyek

\begin{tabular}{|c|l|}
\hline No & \multicolumn{1}{|c|}{ Variabel Risiko } \\
\hline 1 & Proyek yang terlambat membuat budget bertambah \\
\hline 2 & Pergantian staff proyek membutuhkan penambahan biaya \\
\hline 3 & Kurangnya ketersediaan tenaga kerja yang kompeten \\
\hline 4 & Motivasi dan semangat tenaga kerja berkurang karena lamanya proyek \\
\hline 5 & Lebihnya ketersediaan material menjadi limbah proyek (waste) dan tidak efisien \\
\hline 6 & Ketersediaan material yang ada terbatas karena lokasi proyek \\
\hline 7 & Gagalnya pabrikasi material \\
\hline 8 & Pergantian supplier yang terjadi mendekati penutupan proyek menyebabkan cost overrun \\
\hline 9 & $\begin{array}{l}\text { Subkontraktor tidak memiliki pengalaman dan keterampilan kerja yang dibutuhkan untuk } \\
\text { pekerjaan yang ada }\end{array}$ \\
\hline 10 & Terjadi kecelakaan tenaga kerja \\
\hline 11 & Demam penyakit selama pelaksanaan proyek menimpa sebagian besar tenaga kerja \\
\hline 12 & Perubahan definisi scope terlambat yang berakibat tidak tercapainya scope proyek yang baru \\
\hline 13 & $\begin{array}{l}\text { Prioritas proyek tidak jelas dimana pekerjaan yang kurang penting diselesaikan lebih dahulu } \\
\text { dibandingkan dengan pekerjaan yang seharusnya lebih dibutuhkan }\end{array}$ \\
\hline 14 & $\begin{array}{l}\text { Informasi sistem baru menyebabkan terjadinya penambahan pekerjaan di luar scope proyek } \\
\text { yang telah direncanakan }\end{array}$ \\
\hline
\end{tabular}




\section{Analisis Statistik Deskriptif}

Analisis statistik deskriptif dilakukan dengan tujuan untuk menyajikan karakteristik tertentu yang dimiliki suatu sampel data dimana karakteristik data yang menjadi fokus dalam penelitian ini adalah nilai mean, median, dan modus (mode) sampel data. Berdasarkan hasil analisis yang didapat dengan menggunakan program SPSS dan Ms.Excel, dapat diketahui bahwa nilai mean, median, dan mode yang dihasilkan memiliki besaran yang sama untuk seluruh variabel yang disajikan dimana nilai rata-rata tertinggi terdapat pada variabel X43 Struktur Kompleks Didisain Terpisah (Precast) namun Proses Integrasi Gagal untuk Diterapkan.

\section{Analisis Frekuensi}

Analisis frekuensi dilakukan dengan tujuan untuk menyajikan seberapa sering atau seberapa banyak suatu jawaban muncul dari keseluruhan jawaban yang diberikan responden terhadap suatu variabel. Berdasarkan hasil analisis yang didapat, Nilai frekuensi jawaban tertinggi terdapat pada variabel X28, X29, X44, dan X45 dimana diperoleh hasil jawaban yang sama sebesar 1 dari keseluruhan responden. Dari hasil analisis yang didapat, diketahui juga bahwa nilai yang diberikan responden berbeda satu dengan yang lain. Diduga, hal ini disebabkan karena adanya perbedaan tingkat pendidikan, pekerjaan, dan pengalaman kerja responden. Untuk membuktikan benar atau tidaknya hipotesa yang diberikan, maka dilakukan uji Kruskal Wallis dengan menggunakan program SPSS. Adapun hasil pengujian dapat dilihat pada gambar 1-3.

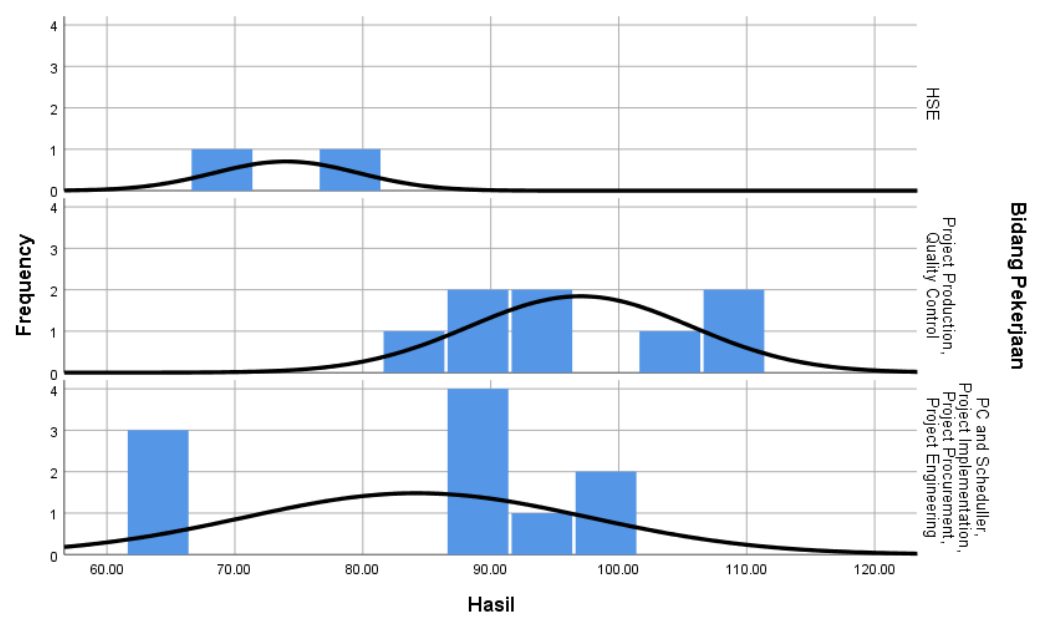

Gambar 1 Histogram Uji Kruskal Wallis dalam Bidang Pekerjaan

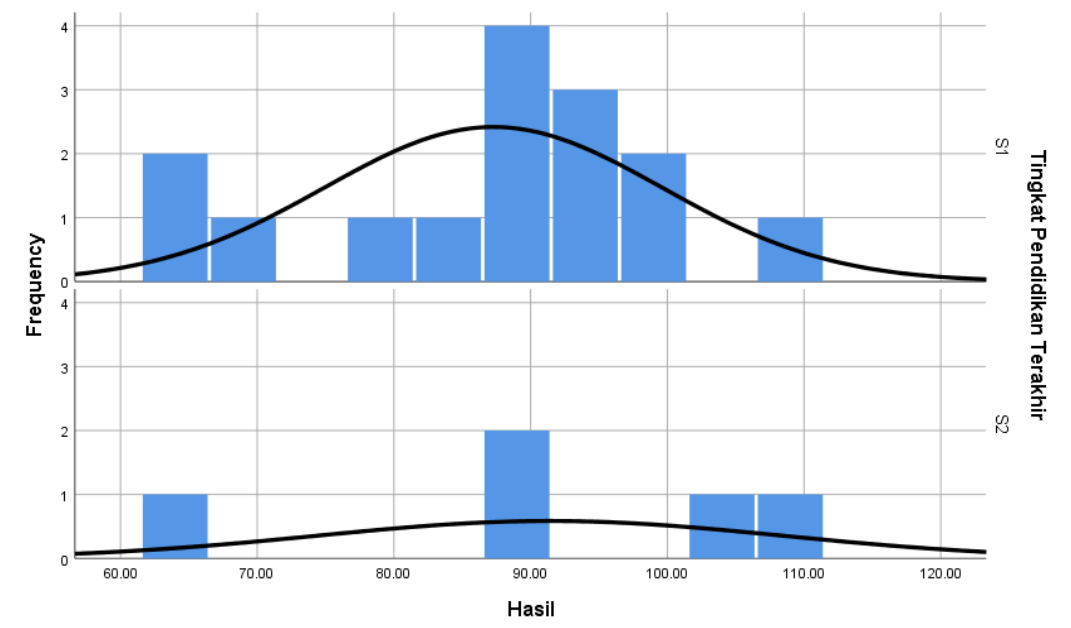

Gambar 2 Histogram Uji Kruskal Wallis dalam Tingkat Pendidikan 


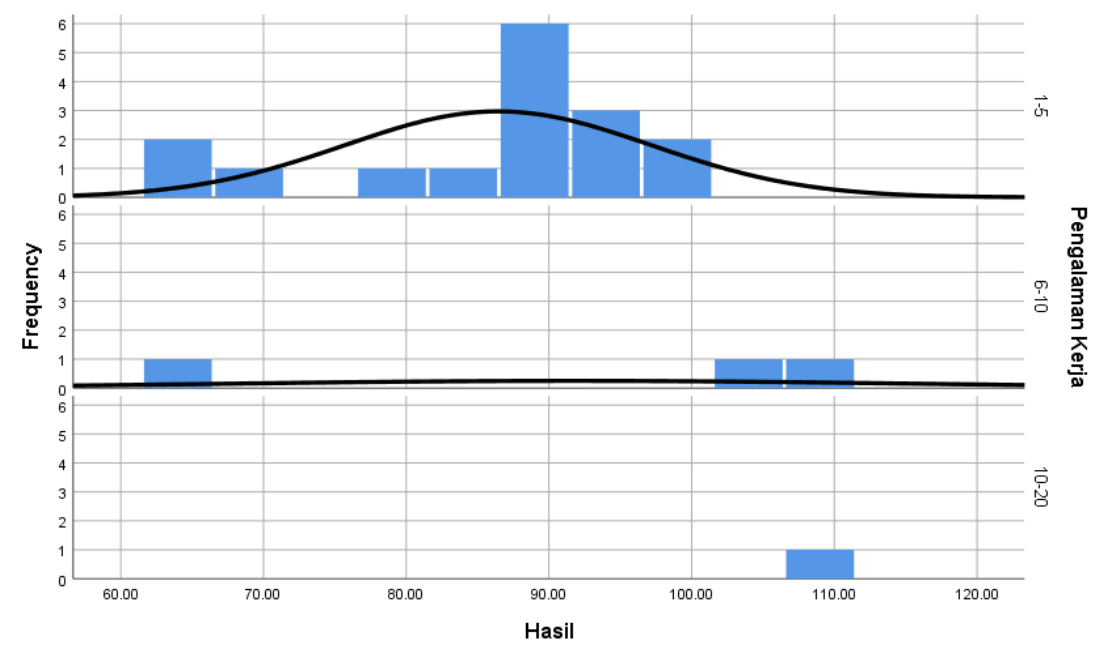

Gambar 3 Histogram Uji Kruskal Wallis dalam Pengalaman Kerja

Berdasarkan hasil pengujian yang dilakukan, diperoleh hasil jawaban yang berbeda-beda antara responden yang satu dengan yang lain dimana faktor pembeda yang paling dominan disebabkan oleh adanya perbedaan dalam bidang pekerjaan, diikuti setelahnya karena ada perbedaan dalam lama pengalaman kerja dan tingkat pendidikan.

\section{Analisis Ranking}

Analisis ranking risiko dilakukan untuk mengetahui ranking atau peringkat risiko dari yang terbesar hingga terkecil berdasarkan data frekuensi dan pengaruh risiko yang terjadi. Analisis ranking ini dilakukan dengan menggunakan metode Analitycal Hierarchy Process (AHP) dengan bantuan program Ms.Excel yang dimulai dari perlakuan normalisasi matriks, penentuan bobot elemen, perhitungan konsistensi matriks, konsistensi hirarki, dan tingkat akurasi, serta perhitungan nilai lokal pengaruh dan frekuensi. Hasil akhir dari pengunaan metode ini adalah nilai akhir risiko (goal) berupa peringkat (ranking) berdasarkan bobot hasil perhitungan. Risiko paling tinggi terdapat pada variabel X31 Demam Penyakit Selama Pelaksanaan Proyek Menimpa Sebagian Besar Tenaga Kerja.

\section{Analisis Level}

Berdasarkan pemeringkatan yang dilakukan diperoleh enam risiko utama yang terjadi dengan kategori level risiko High $(\mathrm{H})$ sebanyak lima jenis dan kategori level risiko Significant (S) sebanyak satu jenis. Risiko utama proyek dapat dilihat pada tabel 4 .

Tabel 4 Risiko Utama Proyek

\begin{tabular}{|c|c|l|c|}
\hline Ranking & Level & \multicolumn{1}{|c|}{ Variabel Risiko } & $\begin{array}{c}\text { Berpengaruh } \\
\text { Terhadap Sasaran }\end{array}$ \\
\hline Rank.1 & $\mathrm{H}$ & $\begin{array}{l}\text { Demam penyakit selama pelaksanaan proyek } \\
\text { menimpa sebagian besar tenaga kerja }\end{array}$ & Resources \\
\hline Rank.2 & $\mathrm{H}$ & $\begin{array}{l}\text { Struktur kompleks didisain terpisah (precast) } \\
\text { namun proses integrasi gagal untuk diterapkan }\end{array}$ & Scope \\
\hline Rank.3 & $\mathrm{H}$ & $\begin{array}{l}\text { Robohnya struktur di tengah pelaksanaan } \\
\text { konstruksi }\end{array}$ & \\
\hline
\end{tabular}


Tabel 4 Risiko Utama Proyek (Lanjutan)

\begin{tabular}{|c|c|c|c|}
\hline Ranking & Level & Variabel Risiko & $\begin{array}{c}\text { Berpengaruh } \\
\text { Terhadap Sasaran }\end{array}$ \\
\hline Rank. 4 & $\overline{\mathrm{H}}$ & $\begin{array}{l}\text { Dibutuhkan pekerjaan dan pengujian ulang } \\
\text { untuk memperbaiki hasil pekerjaan yang salah }\end{array}$ & Scope \\
\hline Rank. 5 & $\mathrm{H}$ & Buruh melakukan mogok bekerja & Schedule \\
\hline Rank. 6 & $\mathrm{~S}$ & $\begin{array}{l}\text { Proyek yang terlambat membuat budget } \\
\text { bertambah }\end{array}$ & Schedule \\
\hline
\end{tabular}

\section{Penanganan Risiko Scope Proyek}

Penanganan risiko terhadap sasaran scope proyek berkaitan erat terhadap masalah mutu hasil pekerjaan yang dilakukan. Adapun penanganan yang dapat dilakukan terhadap variabel-variabel risiko yang diperoleh adalah sebagai berikut:

1. Melakukan peninjauan kembali keberjalanan SMK3L dalam pelaksanaan konstruksi.

2. Pemberian upah yang dapat memengaruhi semangat pekerja.

3. Tidak melakukan penekanan yang berulang-ulang mengenai deadline kegiatan.

4. Melakukan training softskill staff sesuai bidang pekerjaan.

5. Melakukan evaluasi pengerjaan setiap terjadi gagal struktur yang dilaksanakan secara kontinue.

6. Segera melakukan rekondisi struktur dan infrastruktur lingkungan kerja dalam proyek yang rusak.

7. Melakukan pemeriksaan perlatan secara rutin dan selalu melakukan dokumentasi secara rapi.

\section{Penanganan Risiko Schedule Proyek}

Penanganan risiko terhadap sasaran schedule proyek berkaitan erat terhadap masalah waktu atau jadwal pelaksanaan proyek. Adapun penanganan yang dapat dilakukan terhadap variabel-variabel risiko yang diperoleh adalah sebagai berikut:

1. Dilakukan addendum pekerjaan yang menyangkut waktu akibat perubahan lingkup pekerjaan.

2. Melakukan evaluasi keterlambatan setiap terjadi keterlambatan yang dilaksanakan secara continue.

3. Menyepakati metode penyelesaian perselisihan di awal keberjalanan proyek.

4. Melakukan pengujian sampling terlebih dahulu terhadap sistem baru yang direncanakan untuk digunakan dalam proyek.

\section{Penanganan Risiko Resources Proyek}

Penanganan risiko terhadap sasaran resources proyek berkaitan erat terhadap biaya dan sumber daya yang dikerahkan selama pelaksanaan proyek. Adapun penanganan yang dapat dilakukan terhadap variabel-variabel risiko yang diperoleh adalah sebagai berikut:

1. Dilakukan addendum pekerjaan yang menyangkut biaya akibat perubahan lingkup pekerjaan.

2. Pemilihan tenaga kerja yang tepat baik kualitas maupun kuantitasnya terhadap suastu pekerjaan yang diencanakan.

3. Melakukan ketepatan dalam hal pembayaran.

4. Melakukan pengecekan rutin rancangan anggaran biaya.

\section{SIMPULAN}

Pada akhir penelitian ini, dapat dihasilkan kesimpulan yang merupakan jawaban dari rumusan masalah yang dikemukakan. Adapun kesimpulan yang dimaksud adalah sebagai berikut: 
1. Diperoleh 50 jenis variabel risiko proyek yang memberikan dampak negatif dan dapat memengaruhi pengerjaan suatu proyek konstruksi bangunan dalam kaitannnya terhadap sasaran proyek dimana terdapat 20 jenis variabel risiko yang berpengaruh terhadap jadwal proyek, 14 jenis variabel risiko yang berpengaruh terhadap sasasumber daya proyek, dan 16 jenis variabel risiko yang berpengaruh terhadap ruang lingkup proyek.

2. Diperoleh hasil dari analisis risiko yang telah dilakukan terhadap variabel-variabel risiko yang telah diidentifikasi. Adapun hasil analisis yang didapat adalah sebagai berikut:

- Dari hasil analisis statistik deskriptif yang telah dilakukan, diperoleh nilai mean, median, dan mode sama antara hasil dari SPSS dan MS. Excel dimana nilai rata-rata tertinggi terdapat pada variabel X43 Struktur Kompleks Didisain Terpisah (Precast) namun Proses Integrasi Gagal untuk Diterapkan.

- Dari hasil analisis frekuensi yang telah dilakukan, diperoleh hasil jawaban yang berbeda-beda antara responden yang satu dengan yang lain dimana faktor pembeda yang paling dominan disebabkan oleh adanya perbedaan dalam bidang pekerjaan, diikuti setelahnya karena ada perbedaan dalam lama pengalaman kerja dan tingkat pendidikan.

- Dari hasil analisis ranking yang telah dilakukan, diperoleh hasil pemeringkatan tingkat risiko serta 10 besar ranking risiko paling dominan dimana risiko paling tinggi terdapat pada variabel X31 Demam Penyakit Selama Pelaksanaan Proyek Menimpa Sebagian Besar Tenaga Kerja.

- Dari hasil analisis level yang telah dilakukan, diperoleh 6 risiko utama proyek, yaitu pada X31, X43, X42, X46, X20, dan X21 dengan kategori level risiko High (H) sebanyak lima jenis serta kategori level risiko Significant $(S)$ sebanyak satu jenis.

3. Diperoleh penanganan-penanganan risiko yang dapat dilakukan oleh kontraktor terhadap variabel-variabel risiko yang telah diidentifikasi dimana terdapat 7 penanganan terhadap ruang lingkup proyek, 4 penanganan terhadap jadwal proyek, dan 4 penanganan terhadap sumber daya proyek.

\section{SARAN}

Adapun saran yang dapat diberikan berdasarkan hasil analisis yang didapat dalam penelitian ini adalah sebagai berikut:

1. Dalam upaya pengumpulan data, diperlukan alternatif instrumen penelitian yang lebih efisien untuk digunakan. Adapun instrumen yang dimaksud haruslah mudah dan tepat bagi responden dalam mengisi kuisioner yang ada.

2. Dapat dilakukan penelitian lanjutan untuk mengetahui akar penyebab terhadap variabel-variabel risiko yang diangkat.

3. Dapat dilakukan penelitian lain selain pada bangunan bertingkat tinggi seperti pada proyek konstruksi pembuatan saluran irigasi, pembangunan jalan, ataupun pengerjaan jembatan panjang yang menghubungkan dua buah pulau.

4. Pengerjaan penelitian berbasis identifikasi dan analisis risiko seperti ini sebaiknya dimulai dan ditinjau saat magang sehingga data yang diperoleh lebih akurat dan tepat sasaran.

\section{UCAPAN TERIMAKASIH}

Peneliti mengucapkan terimakasih kepada kedua orang tua yang telah memberikan dukungan baik moral maupun materil serta Bapak Setiono S.T., M.Sc. dan Bapak Ir. Sugiyarto M.T. selaku dosen pembimbing yang telah menyediakan waktu, tenaga, dan pikiran untuk mengarahkan peneliti dalam penyusunan skripsi ini. 


\section{REFERENSI}

Cohen, Mark W. PE, and Glen R. Palmer. (2004). Project Risk. Identification and Management. AACE International Transactions

Djojowirono, Soegeng. (2015). Manajemen Konstruksi. Yogyakarta: Biro Penerbit KMTS UGM.

Doran, George T. (Journal November 1981). There's a S.M.A.R.T. Way to Write Management Goals and Objectives. Management Review.

Flanagan and Norman. (1993). Risk Analysis and Management. Royal Institution of Chartered Surveyors.

Jason, Westland. (2003). Project Management Guide Book, Methods 123.

Kendrick, Tom. (2003). Identifying and Managing Project Risk: Essential Tools for Failure-Proofing Your Project. New York: AMACOM.

Kloppenborg, Timothy J., Arthur Shriberg, and Jayashree Venkatraman. (2003). Project Leadership. Vienna: Management Concept.

Newell, Michael W and Marina N. (2004). The Project Management Question and Answer Book. New York: AMACON.

Phillips, Joseph. (2004). PMP Project Management Professional Study Guide. New York: McGraw-Hill.

Project Management Institute. (2004). A Guide to the Project Management Body of Knowledge, third edition. 